\title{
Akvaryum Balıklarından Vatoz Balığı (Hypostomus sp) ve Tetra Balıklarında (Characidae sp) Patolojik ve Parazitolojik İncelemeler
}

\author{
Begüm DURGUN ${ }^{1 a}$ Özgür ÖZDEMİR ${ }^{1 b^{*}}$
}

\author{
${ }^{1}$ Selçuk Üniversitesi Veteriner Fakültesi Patoloji Anabilim Dalı, 42079, Kampüs, Konya, TÜRKİYE \\ ${ }^{a}$ https://orcid.org/0000-0002-4033-4051, ${ }^{b}$ https://orcid.org/0000-0002-1595-0557
}

*Sorumlu yazar: oozdemir@selcuk.edu.tr

\section{Ö Z E T}

Bu çalışmada, Konya ilindeki ticari akvaryum işletmelerinden temin edilen Vatoz ve Tetra Balıklarında iç ve dış parazit varlığının ortaya konulması ve patolojik bulgularının incelenmesi amaçlandı. $\mathrm{Bu}$ amaçla 10 farklı işletmeden temin edilen 50 adet Vatoz Balığı (Hypostomus sp) ve 50 adet Tetra Balığ (Characidae sp) olmak üzere 100 adet balık kullanıldı. Parazitolojik ve patolojik incelemeler sonucunda 32 adet Tetra balığında ve 31 adet Vatoz balığında parazite rastlandı. Tetra balıklarının 24 tanesinde Chilodenella sp, 8 tanesinde Tetrahymana sp, 7 tanesinde Costia sp, 3 tanesinde Rotifera sp (euchlanis), 2 tanesinde Trichodina sp, 2 tanesinde Gastrotricha $\mathrm{sp}$ (Chaetonotus), 1 tanesinde Vorticella sp, 1 tanesinde Ichtyophthirus multifliis tespit edilirken 23 balıkta ise hiç parazite rastlanmamıştır. Vatoz balıklarının; 14'ünde Chilodenella sp, 5'inde Ichtyophthirus multifiliis, 2'sinde Costia sp, 1'er tanesinde Aelosoma sp, Rotifera sp (euchlanis), Gyrodactylus sp ve Dactylogyrus sp belirlenirken 30 adet balıkta ise hiç parazite rastlanmamıştır. Histopatolojik incelemelerde 11 adet Tetra ve 24 adet Vatoz olmak üzere 35 adet balıkta endoparazit görüldü. Bu balıklarda bağırsak lümenlerinde nematode ve Ichtyophthirus multifiilis ile epitellerde Eimeria'ya rastlandı. Solungaçlarda, paraziter irritasyona bağlı epitellerde dejenerasyon ve deskuamasyon görüldü. Parazitlerin yoğun olduğu balıklarda dalakta ve böbreklerde melanomakrofaj merkezlerinde artışlara rastlandı. Sonuç olarak; iki balık türünden elde edilen veriler birlikte değerlendirildiğinde toplam 74 adet ektoparazit olduğu tespit edilmiştir. En çok rastlanan ektoparazit oranları Chilodenella sp (\%51), ardından Costia sp (\%12), Tetrahymana sp (\%11), rotifera $\mathrm{sp}(\% 7)$, Ichtyophthirus multifiliis (\%8), Trichodina $\mathrm{sp}$ (\%3), Gyrodactylus sp (\%1), Dactylogyrus sp (\%1), Aelosoma sp (\%1), Vorticella sp (\%1) olarak belirlenmiştir. $\mathrm{Bu}$ iki balık türü aynı ortamda yaşasalar bile tetra balıklarında vatoz balıklarına göre daha fazla ektoparazit görüldüğ̈̈ belirlenmiş, ancak endoparazit görülme oranı vatozlarda daha fazla bulunmuştur.

\section{Pathological And Parasitological Investigations on Stingray Fish (Hypostomus sp) and Tetra Fish (Characidae sp) from Aquarium Fish}

\section{A B S T R A C T}

In this study, it was aimed to determine internal and external parasites in the stingray and Tetra fish obtained from commercial aquarium enterprises in Konya region and to examine their pathological findings. For this purpose, 50 stingray fish (Hypostomus $\mathrm{sp}$ ) and 50 Tetra fish (Characidae sp) of total 100 fishes were used that obtained from 10 different enterprises. As a result of parasitological and histopathological examinations, parasites were found in 63 fish, including 32 Tetra fish and 31 stingray fish. Parasites detected in tetra fish respectively; Chilodenella sp in 24, Tetrahymana sp in 8, Costia sp in 7, Rotifera sp (euchlanis) in 3, Tichodina sp in 2, Gastrotricha sp (Chaetonotus) in 2, Vorticella sp in 1, Ichtyophthirus multifliis in 1. There were no parasites in 23 fish. The infection numbers in Stingray fishes were detected as; Chilodenella sp (28\%) in 14, Ichtyophthirus multifiliis in 5, Costia sp in 2, Aelosoma sp in 1, Rotifera sp (euchlanis), Gyrodactylus sp and Dactylogyrus sp, while 30 fish had no parasites. Histopathological examination revealed endoparasite in 35 fish, including 11 Tetra and 24 Stingray In these fish, nematodes and Ichtyophthirus multifiilis were found in the intestinal lumens and Eimeria in the epithelium. Degeneration, desquamation and disorganization were seen in epithelium of gill due to parasitic irritation. The data obtained from two fish species were evaluated together, as a result 74 ectoparasites were determined. The most common ectoparasites were Chilodenella sp (51\%), Costia sp (12\%), Tetrahymana $\mathrm{sp}$ (11\%), rotifera sp (7\%), Ichtyophthirus multifiliis (8\%), Trichodina sp (3\%), Gyrodactylus sp (1\%), Dactylogyrus sp (1\%), Aelosoma sp (1\%), Vorticella sp (1\%). Even though these two fish species live in the same environment, tetra fish were found to have more ectoparasites than stingrays, but endoparasitic incidence was found to be higher in stingrays.
MAKALE B İLG ÍS İ

Araștırma Makalesi

Geliş : 21.09.2021

Kabul: 20.10.2021

Anahtar kelimeler:

Akvaryum, vatoz balığı, tetra

balığı, parazitoloji, patoloji

To Cite: $\quad$ Durgun B, Özdemir Ö 2021. Akvaryum Balıklarından Vatoz Balığı (Hypostomus sp) ve Tetra Balıklarında (Characidae sp) Patolojik ve Parazitolojik İncelemeler. MJAVL Sciences. 11 (2) 145-157 


\section{GİRIŞ}

Dünya genelinde yapılan anket sonuçlarına göre stresten kurtulmanın en güzel yollarından biri de hobi olarak akvaryum ile uğraşmaktır. Akvaryum su ürünleri yetiştiriciliği kapsamında da önemli bir sektördür. Birçok ülkede su ürünleri yetiştiriciliğinde akvaryum balığı yeriştiriciliği ticari açıdan önemli bir yere sahiptir (Hekimoğlu 2004). Akvaryum balıkçlık sektörü tüm dünya genelinde tahmini olarak yıllık 7 milyar dolarlık ticareti elinde bulundurmaktadır (Andrews 1990).

Balık yetiştiriciliğinde paraziter hastalıkların artması özellikle son yıllarda üretimi azaltan önemli bir sorun haline gelmiştir. Yaklaşık olarak balıklarda 10.000 parazit türünün bulunduğu bildirilmiştir (Cengizler 2000). Parazitler, doğrudan ya da dolaylı biçimde balıklara değişik oranlarda zarar vererek yoğun ölümlere sebep olmaktadır (Ekingen 1983). Parazitlerin etkileri, parazitin zarar verme şekline, konaklama süresine, konaklama yerine ve konakçılarına göre değişiklik göstermektedir (Roberts 2012). Parazitler kanca, kıskaç ve emeç gibi tutunma organlarıyla deri veya solungaç dokuda hasara neden olarak mikrobiyal hastalık etkenlerinin girişi ve çoğalmaları için uygun ortam hazırlarlar. Bunun dışında endoparazitler de özellikle sindirim sistemi organlarına zararlar verirler. Parazitler balıklarda vitamin eksikliği, halsizlik, zayıflama gibi önemli sorunlara da neden olurlar. Solungaçlara yerleşen parazitler ise solunumu engeller. Parazitlerin metabolik artıkları ile bazı salgıları konakçı için toksik, özellikle larva ve yavru bireylerde öldürücü etkiye neden olabilirler (Grabda 1991).

Parazitlerin olumsuz etkisi sebebiyle akvaryum balıkçılı̆̆ında önemli ekonomik kayıplar şekillenebilir. Bu nedenle parazitin türü, yaşam döngüsü, yaptı̆̆ı zararlar ile konaklama yeri ve ilişkisi gibi biyolojik özelliklerinin çok iyi bilinmesi gerekmektedir (Hoffman 1979). Akvaryumda bulunan balık türlerinin, optimum yaşam ortamları, üreme davranışları ve beslenme şekilleri farklı olsa da, aynı ortamda yaşamaları mümkündür. Bu durum da, hastalık yapan mikroorganizmaların faaliyetlerine olanak vererek birçok problemi ortaya çıkarmaktadır (Doğanay ve ark 1989, Yanar 1998).

Vatoz balığı (Hypostomus sp, Hypostomus plecostomus), pleco (vatoz) ve ortak adı vantuz ağızlı yayın balığı (suckermouth catfish) olarak bilinir. ABD'de Hypostomus ve Pterygoplichthys cinsinden türler için akvaryum endüstrisi tarafından jenerik isimler olarak kullanılmaktadır (Texas Parks ve Wildlife 2012). Türkiyede, vatoz (Hypostomus sp), cüce vatoz (Ancistrus sp), pelerinli vatoz (Pseudogastromyzon myersi) türlerinin ithal edildiği bildirilmiştir (Türkmen ve Alpbaz 2001).

Tetra balığı Characidae familyası içerisinde yer alan; temiz sularda yaşayan tropikal ve subtropikal büyük bir türdür (Nelson 1994). Küçük balıklar ve omurgasızlarla beslenen karnivor özellikte ve yıl boyunca üreyebilen balıklardır (Ribeiro Neto ve ark. 1998; Magalhaes ve ark. 2004; Gandini ve ark. 2012).Türkiyede, tetraların gümüş tetra, siyah tetra, küçük burunlu ve büyük burunlu tetra, 1şıklı tetra, gül tetra, şebboy tetra, limon tetra, imparator tetra, gökkuşağ tetra, kardinal tetra, neon tetra ve kongo tetra gibi türleri bildirilmiştir (Türkmen ve Alpbaz 2001).

Akvaryum balıklarıyla ilgili çalışmalara ülkemizde az sayıda rastlanmaktadır. Bu çalışmada Konya ilinde satışa sunulan akvaryum balıklarında Vatoz ve Tetra türlerindeki iç ve dış parazit varlığının ortaya konulması ve bunların meydana getirdiği patolojik bulgularının incelenmesi amaçlanmıştır.

\section{MATERYAL VE METOT}

Çalışmanın materyalini 10 ayrı işletmeden beşer adet Tetra ve Vatoz balığı olmak üzere toplamda 100 adet canlı balık oluşturdu. Çalışma, Selçuk Üniversitesi Veteriner Fakültesi Deney Hayvanları Üretim ve Araştırma Merkezi Etik Kurulu (SÜVDAMEK)'nun 27.07.2018 tarih ve 2018/82 karar say1lı izniyle yapıldı.

\section{Parazitolojik inceleme (Natif muayene)}

Çalışma materyali olarak temin edilen canlı balıkların, çıplak gözle ve büyüteç yardımı ile parazit muayenesi yapıldı. Ardından natif muayene için; deri, solungaç ve yüzgeçlerden lam ile kazıntı alınarak kendi ıslaklığı ile üzerine lamel kapatılıp 1şık mikroskobunda incelendi (Erer 2009).

\section{Patolojik inceleme}

Paraziter incelemesi yapılan balıklar karanfil yağıyla anestezi altına alındıktan sonra dekapitasyon yöntemiyle ötanazi edildi. Balıkların çok küçük olmaları sebebiyle sadece karın boşluğu açılarak ve bütün olarak \%10'luk tamponlu formolinde tespit edildi. Tespit işleminden sonra bu balıklarda doku küçültme ve trimleme işlemi bütün balık üzerinde, her biri karın boşluğunu kapsayacak şekilde 3 seri dilim yapıldı ve bu dilimler örnek olarak alındı. Ayrıca solungaçlardan da örnekler alındı. Bu dokular 24 saat akan suda yıkandı. Daha sonra rutin doku takip prosedürü uygulanan dokular parafine gömüldü. Histopatolojik incelemeler için her bloktan mikrotomla $5 \mu \mathrm{m}$ kalınlığında kesitler alınarak Hematoksilen Eosin (HxE) ile boyandı (Luna 1968) ve ışık mikroskobunda incelendi. 


\section{BULGULAR VE TARTIȘMA}

\section{Parazitolojik Bulgular}

Tetra ve Vatoz balıklarının natif parazitolojik muayenesinde; 50 adet Tetra balığının 27 tanesinde (\%54) ve 50 adet Vatoz balığının 20 tanesinde (\%40) ektoparazit bulundu. Natif muayenelerde Gyrodactylus sp, Chilodenella sp, Costia sp, Tetrahymana sp, Trichodina sp, Dactylogyrus sp, Ichthyophthirius multifiliis, Rotifera (Euchlanis) sp, Vorticella sp ve Aelosoma sp'ye rastlandı. İşletme bazında parazit varlığı değerlendirildiğinde (Çizelge 1), 3 işletmede (1,2 ve 3 nolu işletmeler) hem tetra hem de vatozlarda parazite rastlanmazken, 2 işletmede ise ( 9 ve 10 nolu işletme) tetralarda parazit tespit edilmesine rağmen vatozlarda parazit bulunamadi.

Çizelge 1. Parazit türüne göre enfeste işletmeler

\begin{tabular}{|c|c|c|c|c|c|c|c|c|c|c|c|c|c|c|c|c|c|c|c|c|c|}
\hline \multirow{3}{*}{ Parazit türü } & \multicolumn{20}{|c|}{ Akvaryum Balığı İşletmeleri } & \multirow{3}{*}{$\begin{array}{c}\text { Toplam } \\
\text { Enfeste } \\
\text { İşletme sayısı }\end{array}$} \\
\hline & \multicolumn{2}{|c|}{1} & \multicolumn{2}{|c|}{2} & \multicolumn{2}{|c|}{3} & \multicolumn{2}{|c|}{4} & \multicolumn{2}{|c|}{5} & \multicolumn{2}{|c|}{6} & \multicolumn{2}{|c|}{7} & \multicolumn{2}{|c|}{8} & \multicolumn{2}{|c|}{9} & \multicolumn{2}{|c|}{10} & \\
\hline & $\mathbf{T}$ & $\mathbf{v}$ & $\mathbf{T}$ & $\mathbf{V}$ & $\mathbf{T}$ & $\mathbf{V}$ & $\mathbf{T}$ & $\mathbf{V}$ & $\mathbf{T}$ & $\mathbf{V}$ & $\mathbf{T}$ & $\mathbf{V}$ & $\mathbf{T}$ & $\mathbf{V}$ & $\mathbf{T}$ & $\mathbf{V}$ & $\mathbf{T}$ & $\mathbf{V}$ & $\mathbf{T}$ & $\mathbf{V}$ & \\
\hline Chilodenella & - & - & - & - & - & - & + & + & + & + & + & + & + & + & + & + & + & - & + & - & 7 \\
\hline Costia & - & - & - & - & - & - & - & - & - & - & + & + & + & + & + & - & - & - & - & - & 3 \\
\hline Trichodina & - & - & - & - & - & - & + & - & - & - & - & - & - & - & - & - & - & - & - & - & 1 \\
\hline Dactylogyrus & - & - & - & - & - & - & - & - & - & + & - & - & - & - & - & - & - & - & - & - & 1 \\
\hline Gyrodactylus & - & - & - & - & - & - & - & - & - & - & - & - & - & - & - & + & - & - & - & - & 1 \\
\hline Rotifera & - & - & - & - & - & - & + & - & - & - & + & - & - & + & - & - & - & - & - & - & 3 \\
\hline Vorticella & - & - & - & - & - & - & - & - & - & - & + & - & - & - & - & - & - & - & - & - & 1 \\
\hline Aelosoma & - & - & - & - & - & - & - & - & - & + & - & - & - & - & - & - & - & - & - & - & 1 \\
\hline Ichtyophithirus & - & - & - & - & - & - & + & - & - & + & - & + & - & - & - & - & - & - & - & - & 3 \\
\hline Tetrahymena & - & - & - & - & - & - & - & - & - & - & + & - & + & - & + & - & + & - & + & - & 5 \\
\hline Gastrotricha & - & - & - & - & - & - & - & - & - & - & - & - & - & - & + & - & + & - & - & - & 2 \\
\hline
\end{tabular}

T: Tetra balığı, V: Vatoz balığı

Tetra balıklarının 24 tanesinde Chilodenella sp (\% 48) (Şekil 1A), 8 tanesinde Tetrahymana sp (\%16) ( Şekil 1.D), 7 tanesinde Costia sp (\%14) (Şekil 1.B), 3 tanesinde Rotifera sp (Euchlanis sp) (\%6) (Şekil 1.E-F), 2 tanesinde Tichodina sp (\%4) (Şekil 1.H), 2 tanesinde Gastrotricha sp (Chaetonotus) (\%4) (Şekil 1.G), 1 tanesinde Vorticella sp (\%2) (Şekil 1.C), 1 tanesinde Ichtyophithirus multifiliis (\%2) (Şekil 1.K-L) tespit edilirken 23 (\% 46) balıkta ise hiç parazite rastlanmamıştır. Natif muayenede 21 balığın 2 ve daha fazla parazit türü barındırdığı tespit edilmiştir (Çizelge 2).

Çizelge 2. Tetra ve Vatoz balı̆ğnda natif ve histopatolojik muayene sonucu bulunan ektoparazit ve endoparazi saylları

\begin{tabular}{|c|c|c|c|c|c|c|c|c|c|c|c|c|c|c|c|c|c|c|c|}
\hline \multirow[b]{3}{*}{ 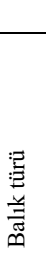 } & \multirow[b]{3}{*}{ 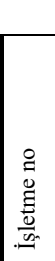 } & \multirow[b]{3}{*}{ 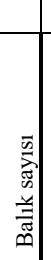 } & \multicolumn{11}{|c|}{ Ektoparazitler } & \multicolumn{4}{|c|}{ Muayene șekli } & \multicolumn{2}{|c|}{ Toplam } \\
\hline & & & \multirow{2}{*}{ 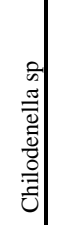 } & \multirow[b]{2}{*}{ 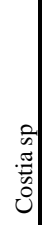 } & \multirow{2}{*}{ 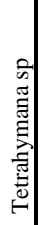 } & \multirow{2}{*}{ 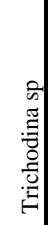 } & \multirow{2}{*}{ 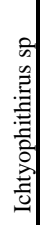 } & \multirow{2}{*}{$\begin{array}{l}\text { की } \\
. \\
\text { : } \\
\text { ज्ञ } \\
0 \\
\text { ज्ञ }\end{array}$} & \multirow{2}{*}{ 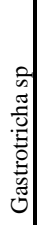 } & \multirow{2}{*}{ 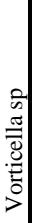 } & \multirow{2}{*}{ 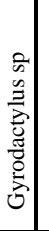 } & \multirow{2}{*}{$\begin{array}{l}0 \\
0 \\
0 \\
\underbrace{}_{0} \\
0 \\
0 \\
0 \\
0 \\
0\end{array}$} & \multirow{2}{*}{ 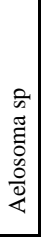 } & \multirow{2}{*}{ 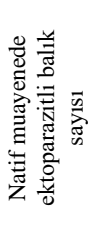 } & \multirow{2}{*}{ 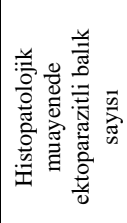 } & \multicolumn{2}{|c|}{$\begin{array}{l}\text { Histopatolojik } \\
\text { muayenede } \\
\text { Endoparazit }\end{array}$} & \multirow{2}{*}{$\begin{array}{c}\text { Iki ve } \\
\text { daha fazla } \\
\text { parazitle } \\
\text { enfeste } \\
\text { balık } \\
\text { sayıs1 }\end{array}$} & \multirow[t]{2}{*}{$\begin{array}{c}\text { Parazitli } \\
\text { balık } \\
\text { say1s1 }\end{array}$} \\
\hline & & & & & & & & & & & & & & & & 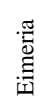 & $\begin{array}{l}\overrightarrow{0} \\
\stackrel{\Xi}{\pi} \\
\ddot{\Xi}\end{array}$ & & \\
\hline \multirow{10}{*}{ 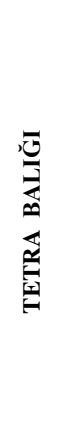 } & $\mathrm{T} 1$ & 5 & - & - & - & - & - & - & - & - & - & - & - & - & - & 1 & 2 & 1 & 2 \\
\hline & $\mathrm{T} 2$ & 5 & - & - & - & - & - & - & - & - & - & - & - & - & - & - & 1 & - & 2 \\
\hline & T3 & 5 & - & - & - & - & - & - & - & - & - & - & - & - & - & - & - & - & - \\
\hline & $\mathrm{T} 4$ & 5 & 2 & - & - & 2 & 1 & 1 & - & - & - & - & - & 4 & - & - & 1 & 2 & 4 \\
\hline & T5 & 5 & 3 & - & - & - & - & - & - & - & - & - & - & 3 & - & - & 1 & - & 4 \\
\hline & T6 & 5 & 3 & 2 & 1 & - & - & 2 & - & 1 & - & - & - & 4 & - & - & 1 & 4 & 4 \\
\hline & $\mathrm{T} 7$ & 5 & 5 & 1 & 1 & - & - & - & - & - & - & - & - & 5 & - & - & 3 & 4 & 5 \\
\hline & T8 & 5 & 5 & 4 & 2 & - & - & - & 1 & - & - & - & - & 5 & - & - & 1 & 5 & 5 \\
\hline & T9 & 5 & 4 & - & 2 & - & - & - & 1 & - & - & - & - & 4 & - & - & 1 & 3 & 4 \\
\hline & $\mathrm{T} 10$ & 5 & 2 & - & 2 & - & - & - & - & - & - & - & - & 2 & - & - & - & 2 & 2 \\
\hline
\end{tabular}




\begin{tabular}{|c|c|c|c|c|c|c|c|c|c|c|c|c|c|c|c|c|c|c|c|}
\hline & Toplam & 50 & 24 & 7 & 8 & 2 & 1 & 3 & 2 & 1 & - & - & - & 27 & - & 1 & 11 & 21 & 32 \\
\hline \multirow{11}{*}{ 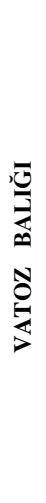 } & V1 & 5 & - & - & - & - & - & - & - & - & - & - & - & - & - & - & - & - & \\
\hline & V2 & 5 & - & - & - & - & - & - & - & - & - & - & - & - & - & - & 3 & - & 3 \\
\hline & v3 & 5 & - & - & - & - & - & - & - & - & - & - & - & - & - & - & 3 & - & 3 \\
\hline & V4 & 5 & 3 & - & - & - & - & - & - & - & - & - & - & 3 & - & - & - & - & 3 \\
\hline & v5 & 5 & 2 & - & - & - & 1 & - & - & - & - & 1 & 1 & 4 & 1 & - & 2 & 2 & 3 \\
\hline & V6 & 5 & 3 & 1 & - & - & 3 & - & - & - & - & - & - & 4 & - & - & 4 & 4 & 5 \\
\hline & V7 & 5 & 4 & 1 & - & - & - & 1 & - & - & - & - & - & 5 & - & - & 4 & 5 & 5 \\
\hline & V8 & 5 & 2 & - & - & - & 1 & - & - & - & - & - & - & 3 & 1 & - & 4 & 3 & 5 \\
\hline & V9 & 5 & - & - & - & - & - & - & - & - & 1 & - & - & 1 & - & - & 2 & 1 & 2 \\
\hline & $\mathrm{V} 10$ & 5 & - & - & - & - & - & - & - & - & - & - & - & - & - & - & 2 & - & 2 \\
\hline & Toplam & 50 & 14 & 2 & - & - & 5 & 1 & - & - & 1 & 1 & 1 & 20 & $2^{*}$ & - & 24 & 15 & 31 \\
\hline
\end{tabular}

V5 işletmesinde aynı balıkta hem natif hem de histopatolojik incelemede parazit tespit edilirken, V8 işletmesinde bir balıkta sadece histopatolojik incelemede parazit tespit edildi. Bu sebeple tespit edilen parazit sayıs1 $73+1=74$ olarak belirlenmiştir.

Vatoz balıklarının natif muayenesinde 20 (\%40) tanesinde parasite rastlanırken 30 tanesinde (\%60) hiç parazite rastlanmamıştır. Bu balıklarda 14 adet Chilodenella sp (\%28) (Şekil 1.A), 5 adet Ichtyophthirus multifiliis (\%10) (Şekil 1.K-L), 2 adet Costia sp (\%4) (Şekil 1.B), 1 adet Rotifera sp (Euchlanis sp) (\%2) (Şekil 1.E-F), 1 adet Dactylogyrus sp (\%2) (Şekil 1.L), 1 adet Gyrodactylus sp (\%2) (Şekil 1.M), 1 adet Aelosoma sp (\%2) tespit edilmiştir (Şekil 1.N). Natif ve histopatolojik muayenede 15 balıkta 2 ve daha fazla parazit türü bir arada tespit edilmiştir (Çizelge 2).

Iki balık türü birlikte değerlendirildiğinde natif muayenede toplam 74 adet ektoparazit olduğu tespit edilmiştir (Şekil 2). Bazı balıklarda (36 adet) birden çok parazit tespit edilmiştir. En çok rastlanan ektoparazit Chilodenella sp (\%51), ardından Costia sp (\%12), Tetrahymana sp (\%11), Ichtyophthirus multifiliis (\% 8), Rotifera sp (Euchlanis sp) (\%5), Trichodina sp (\%3), Gastrotricha sp (\%3), Gyrodactylus sp (\%1), Dactylogyrus sp (\%1), Aelosoma sp (\%1), Vorticella sp (\%1) olarak belirlenmiştir (Çizelge 2). 

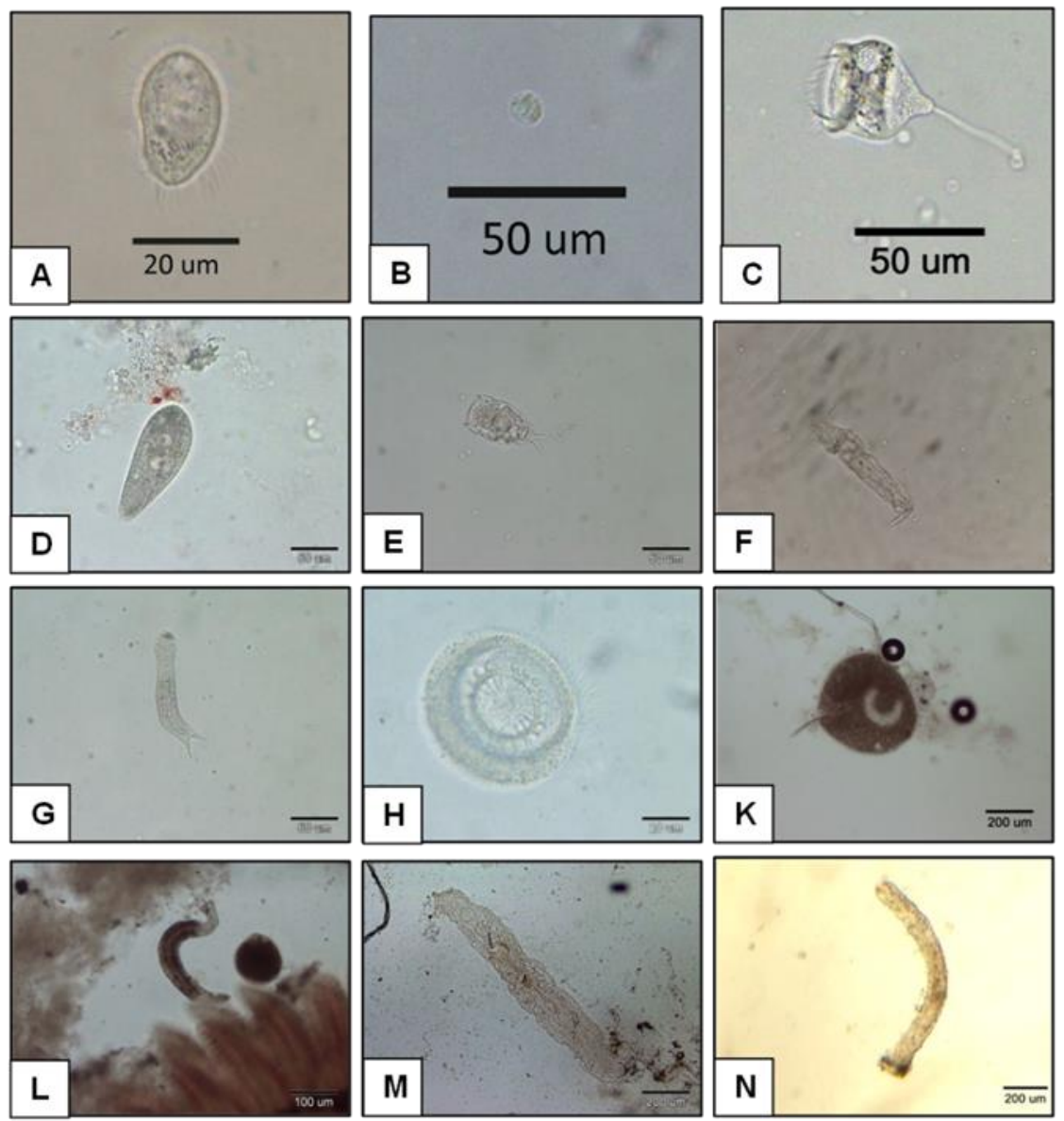

Şekil 1. Natif muayenede tespit edilen parazitler. A. Chilodenella sp. B. Costia sp. C. Vorticella sp. D. Tetraymena sp. E-F. Rotifera sp (Euglanis sp). G. Gastrotricha sp (Chaetonotus). H. Trichodina sp. K. Ichtyophthirus multifiliis. L. Dactylogyrus sp ve Ichtophthirus multifiliis. M. Gyrodactylus sp. N. Aelosoma sp

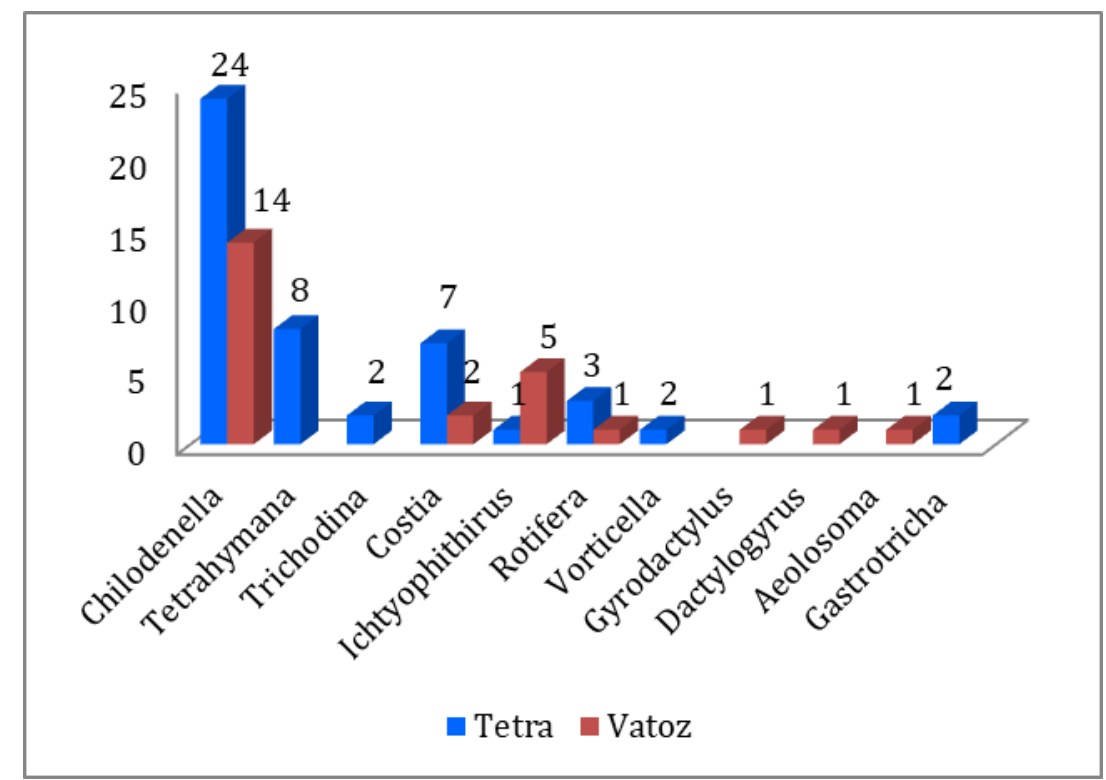

Şekil 2. Tüm balıklardan tespit edilen ektoparazitlerin (74 adet) türlere göre dağılımı

Parazitolojik ve histopatolojik incelemeler sonucunda 32 adet Tetra balığında ve 31 adet Vatoz balığında olmak üzere toplamda 63 balıkta parazite rastlandı. Bu çalışma sonucunda parazitle enfekte balık oranı toplamda \% 63 olarak belirlendi 


\section{Histopatolojik bulgular}

Histopatolojik muayenelerde 50 adet Tetra balığının 11 tanesinde (\%22), 50 adet Vatoz balığının 24 tanesinde (\%48) endoparazit (nematode, Eimeria sp) bulundu. Endoparazit olan Tetra balıklarından bir tanesinde nematodla birlikte Eimeria sp'ye rastlandı. Vatoz balıklarında ise 2 balıkta bağırsak lümeninde nematodla birlikte Ichtyophthirus multifiilis etkeni görüldü. Parazitle enfeste olmayan balıklarda solungaçlar normal görünümdeydi (Şekil 3.A). Parazitle enfeste 2 vatoz balığının solungacında Ichtyophthirus multifiis etkeni görüldü (Şekil 3.B-C). Her iki balık türünde de yoğunlukla solungaçlarda hiperemi (Şekil 3.D) görülürken, 1 tetra ve 1 vatoz balığında solungaçlarda kanama, tetra balıklarının birkaçında solungaç sekunder lamellerinde ödem (Şekil 3.E) ve hiperplaziler (Şekil 3.F,H) görülürken, vatoz balıklarının bazılarında primer lamellerin uç kısmındaki sekonder lamellerde düzleşme, epitellerde dejenerasyon ve deskuamasyon, pirimer lamellerin uç kısımlarında eozinofilik granüler hücreler (Şekil 3.G), solungaçta kalsifikasyon, epitellerde nekroz ve dökülme, lenfoid dokuda artış izlendi.

Karaciğer genelde normal görünümde olup, her iki balık türünde de hepatositlerde hidropik dejenerasyona (Şekil 4.A) rastlanırken tetra balıklarının bazılarında karaciğerde keskin kenarlı yağ vakuolleri (Şekil 4.B) ve lenfoid hücre infiltrasyonları görüldü.

Bir vatoz ve dört tetra balığında dalakta yoğun melanomakrofaj merkezleri (Şekil 4.C) ve bir tetra balığında dalakta nekrotik granülom (Şekil 4.D) dikkat çekti.

Böbreklerde tubulus epitellerinde dejenerasyon ve nekroz ile sitoplazmasında hemosiderin pigmenti birikimleri (Şekil 4.F) görüldü. Tubulus lümenlerinde genişleme ve dilatasyon (Şekil 4.G-H) ile yer yer kistik tubuluslara rastlandı (Şekil 4.H). Bazı tubulus lümenlerinde proteinden zengin sıvı birikimleri gözlendi.

Bir tetra balığında midede ülser oluşumuna rastlandı. Bağırsakların histopatolojik incelenmesinde epitellerde dejenerasyon ve nekroz ile lamina propriyada mononükleer hücre ve makrofaj içeren yangısal infiltrasyonlar dikkati çekti. Ayrıca Vatoz balıklarında 23 olguda bağırsak lümeninde nematoda (Şekil 5A-E) ve bir olguda da Ichtyophthirus multifiliis'e (Şekil 5C), tetra balıklarında ise 11 nematod (Şekil 5.D) ve bir Eimeria sp'ye, (Şekil 5.E) rastlandı. Ayrıca iki vatoz balığında bağırsaklarda balık yumurtası, bir olguda da farinks (Şekil 5.F) ve plorik seka'da ülser görüldü.

Genelde deri normal görünümde olup, natif muayenede parazite rastlanmayan bir tetra balığında deride epidermisde hidropik dejenerasyon görüldü (Şekil 5.G).

Bir vatoz balığının karın boşluğunda nematod gözlendi. Tetra balıklarından bir tanesinde karın duvarında yangı, bir tanesinde de karın duvarında kas dokuda nekroz ve hücre infiltrasyonu (Şekil 5.H) ve bir tanesinde de yağ dokuda kolesterin kristallerine benzer yapılar olduğu belirlendi.

İki tetra balığında normal yapıda intrahepatik pankreasa rastlanırken, bir tetra ve bir vatoz balığında hermafroditliğe (ovotestis yapıs1) rastland1. 

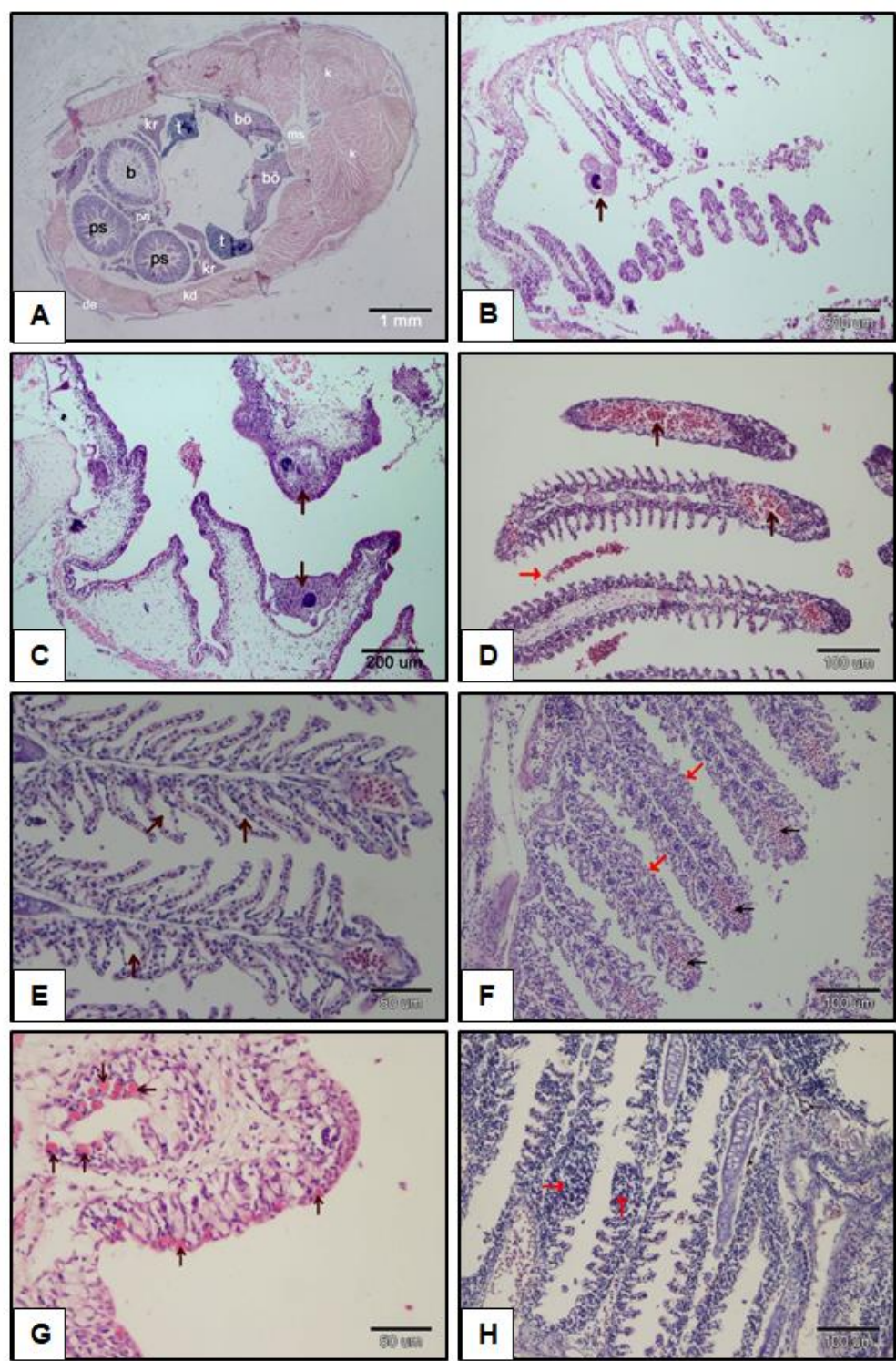

Şekil 3. A.Tetra balığının enine kesiti. HxE. k:kas, ms:medulla spinalis, bö:böbrek, t:testis, Kr: karaciğer, ps:plorik keseler, b:bagırsak, pn: pankreas, kd:karın duvarı, de:deri. B-H. Solungaçlardaki histopatolojik değişiklikler, HxE. BC. Solungaç lümeninde ve epitellerinde Ichtyophthitus multifiliis kesiti (ok). Vatoz balı̆̆ı. D. Solungaçlarda hiperemi (sihay ok) ve kanama (kırmızı ok). Vatoz balığı. E. Solungaç, sekunder lamellerde ödem (oklar). Tetra balığı. F. Primer lamellerde hiperemi (siyah oklar) ve sekunder lamellerde hiperplaziler (kırmızı oklar). Tetra balığı. G. Solungaç kemerinde eozinofilik granüler hücreler. Vatoz balığı. H. Solungaçta sekunder lamellerde hiperplaziler (oklar). Vatoz balığı. 

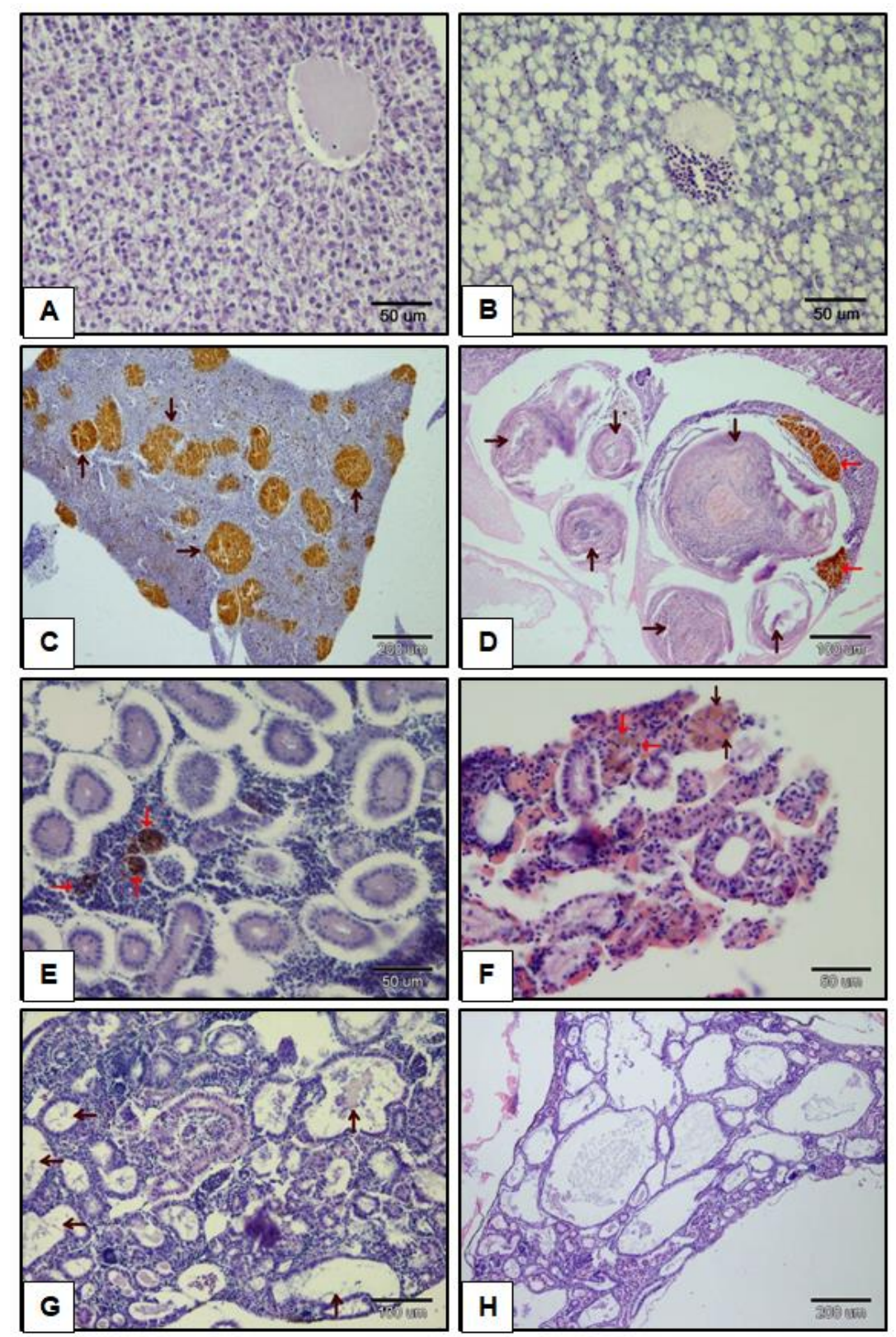

Şekil 4. A. Karaciğer, hepatositlerde yaygın dejenerasyon. Vatoz balığı. HxE. B. Karaciğer, hepatositlerde yağlanma. Tetra balığı. HxE. C. Dalakta melanomakrofaj merkezlerde artış (oklar). Tetra balığı. HxE. D. Dalak nekrotik granülomlar (siyah oklar) ve melanomakrofaj merkezlerde artışlar (kırmızı oklar). Tetra balığı. HxE. E. Böbrekte pigment (melanomakrofajlar) (oklar). Tetra balığı. HxE. F. Böbrekte interstisyumda (kırmızı oklar) ve tubulus lümenlerinde (siyah oklar) hemosiderin pigmenti. Tetra balığı. HxE. G-H. Böbreklerde tubuluslarda dilatasyonlar (oklar) ve kistik yapılar. Tetra balı̆̆ı. HxE. 

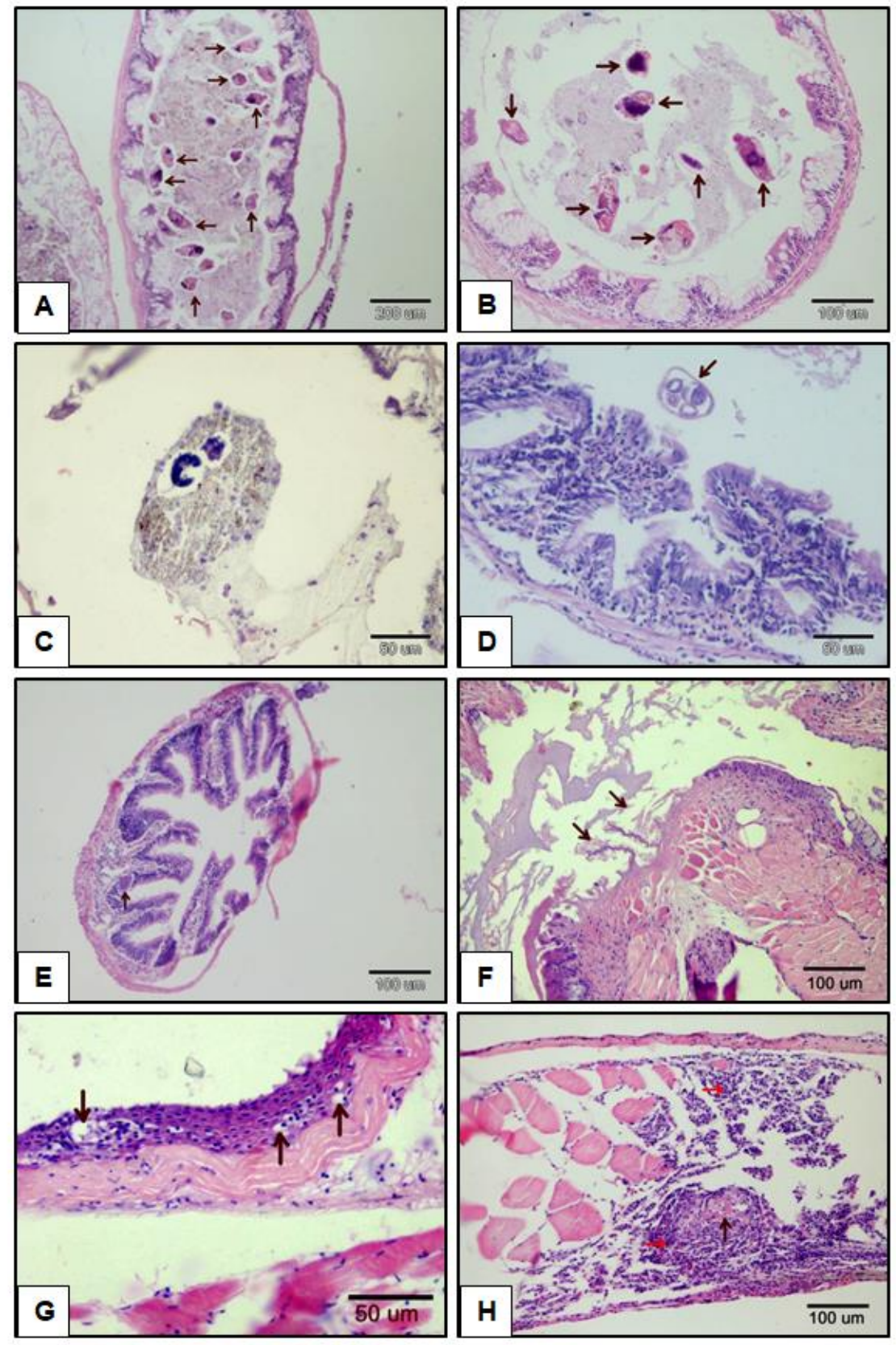

Şekil 5. A-B. Bağırsak lümeninde parazit kesitleri (oklar). Vatoz balığı. HxE. C. Ich. multifiliis kesiti. D Bağırsak lümeninde nematod kesiti (ok). Tetra balı̆̆ı. HxE. E. Bağırsak epitelinde Eimeria sp kesiti (oklar). Tetra balığı. HxE. F. Farinks geçişinde ülser. Tetra balığı. HxE Şekil G. Deride epidermisde hidropik dejenerasyon (oklar). Tetra balığı. HxE. H. Kasta nekroz (siyah oklar) ve lenfoid hücre infiltrasyonu (kırmızı oklar). Karın duvarı. Tetra balığı. HxE.

Ülkemizde yaklaşık 10 milyon adet yıllık pazarı bulunan akvaryum balığı ithali yapılmakta olup (Alpbaz 1993, Tolon ve Emiroğlu 2014), bu ithal balıklarla birlikte gelen parazitlerle balıkların parazit biyoçeşitliliği de artmaktadır. Ülkemizde ithalat yoluyla gelen "Damızlık Harici Canlı Hayvanlar"ın kontrolleri Tarım ve Köyişleri Bakanlığı'nca gümrüklerde yapılmasına rağmen (Resmi gazete 2003), kontrollerin yeterli olmadığı, halen balıkların enfekte olmaya devam ettiği görülmektedir. Akvaryum balığı ithalatında önde olan avrupa birliği ülkelerinin tercih ettiği balıkların başında neon ve cardinal tetra balıkları gelmektedir (Hekimoğlu 2006). Vatozlar ise karma akvaryumların vazgeçilmezlerinden bir tanesi olup akvaryumlardaki yosunları temizlemeleri için tercih edilmektedir (https://en.wikipedia.org/wiki/Hypostomus). Bu çalışmada Konya ilinde de çokça tercih edilen tetra ve vatoz balıklarının ekto ve endoparazitleri natif ve histopatolojik yöntemlerle incelendi ve bunların meydana getirdiği patolojik değişiklikler ortaya konuldu 
Akvaryum balığı ithalat ve ihracatının tüm dünyada artması sonucu balık hastalıklarının ülkeler arası taşınması da yaygınlaşmıştır. Bu sebeple balık hastalıkları, bu sektörde önemli problemler arasında yer almaya başlamıştır (Lievens ve ark. 2011; Mankhakhet ve ark. 2012). Paraziter enfestasyonlar akvaryum balıklarının önemli enfeksiyöz hastalıklarından olup, kalabalık barındırılan sistemlerde önemli verim kayıplarına neden olur (Koyuncu 2002). Balık parazitleriyle ilgili çalışmalara 1931 yılında başlanmış, sonrasında ise farklı araştırıcıların tatlısu, deniz ve akvaryum balıklarının parazit faunalarını çalıştığı bildirilmiştir (Öktener 2003). Bu çalışmada da yetiştiriciliği yapılan Tetra balığı (Characidae sp) ve Vatoz balığı (Hypostamus sp) türlerininektoparaziter ve endoparaziter enfestasyonları parazitolojik ve patolojik yönden incelendi

Parazitle enfeste balıklarda klinik belirtiler, parazitin canlıdaki yerleşim yerine gore değişmekle birlikte genelde solunum güçlüğü, yüzme bozukluğu, iştahsızlık, bir araya toplanma, havuz kenarlarına sürtünme gibi klinik semptomlar göstermektedirler. Makroskobik olarak ise kaşeksi, vücut yüzeyinde mavimsi tabaka oluşması, pullarda dikleşme ve dökülme, bazen yüzgeç dipleri ve solungaçlarda hiperemi ve kanamalar görülebilir (Erer 2009). Melek balıklarında (Ürkü ve Yardımcı 2013) ve Japon balıklarında (Kerek ve Özdemir 2016) yapılan çalışmalarda, balıkların makroskobik olarak hiçbir hastalık belirtisi göstermemelerine rağmen natif ve histopatolojik incelemede çok sayıda parazite rastlandığı bildirilmiştir. Bu çalışmada da makroskobik hiçbir bulguya rastlanmamasına rağmen natif muayenede 27 tetra ve 20 vatoz balığında olmak üzere toplamda 47 balıkta ektoparazit tespit edildi

$\mathrm{Bu}$ araştırmada en fazla teşhis edilen parazit olan Chilodenella sp’ye, Tetra balıklarının 24 tanesinde (\%48), Vatoz balıklarının 14 tanesinde (\%28) rastlanmıştır. Daha önce yapılan çalışmalarda; Koyuncu (2009) moli balıklarında \%1.1, Şahin (2004) Japon balığında \%10, Kerek ve Özdemir (2016) ise Japon balıklarında \%42 ve Lepisteslerde \%6 olarak bulmuştur. Çalışmamızın verileri önceki çalışmalara oranla daha yüksektir. Bu durum özellikle Konya ilindeki akvaryum balıklarında bu parazitle enfestasyonun artarak devam ettiğini göstermektedir.

Tetrahymena türleri ülkemizde akvaryum balıklarından Lepistes, zebra çiklit, sarı prenses (Kayış ve ark 2009; Kayış ve ark. 2013) ile discus balıklarında (Işık ve ark. 2016) bildirilmiştir. Çalışmamızda en fazla görülen parazit türlerinden biri olan Tetrahymana sp'ye 8 tetra balığının solungaç ve derisinde rastlanmış, aynı işletmeden getirilmelerine rağmen vatoz balıklarında ise tespit edilememiştir. Bu durum parazitin tür tercihine yorumlanmıştır.

Rotiferaların gerçek parazit olup olmadığı halen tartışmalıdır. Bu parazitler deri ve solungaçlarda irritasyona sebep oldukları bildirilmiştir (Stoskopf 1993). Euchlanis sp'de rotifera grubu altında yer alır (https://species.wikimedia.org/wiki/Euchlanis). Bulguroğlu ve Korun (2015) sarı ve mavi prenses ile çiklit balıklarının derilerinde Euchlanis sp'ye rastladıklarını bildirmişlerdir. Bu çalışmada da hem tetra (2) hem de vatozda (1) Euchlanis sp tespit edilmiştir. Tespit edilen parazitlere balıkların hem deri hem de solungacında rastlanmış olması parazitin farklı türleri enfeste etme potansiyeli olduğunu ortaya koymaktadır.

Çok kirli ve oksijensiz sularda sorun oluşturan Vorticella türleri, su ve oksijen kalitesi düzelince kendiliğinden kaybolurlar (Tınar ve Umur 2015). Kayış ve ark. (2013) zebra balığının solungaçlarında, Mohammadi ve ark. (2012) diskus ve astronot balıklarının yüzgeç ve solungaçlarında (\%10), Işı ve ark. (2016) bir Diskus balığında Vorticella sp'ye rastladıklarını bildirmişlerdir Çalışmamızda bir tetra balığının solungacında Votricella sp'ye rastlamıştır. Bu durum araştırıcıların da (Mohammadi ve ark. 2012, Kayış ve ark. 2013) bildirdiği gibi akvaryum sularının kirli ve oksijensiz olmasına bağlanmıştır.

Bütün Trichodina sp türleri, olumsuz çevre koşullarında hassaslaşan balıkların vücut yüzeyinin savunma mekanizmasını bozarak çoğalabilirler (Özer 1999). Türkiye'de Kayış ve ark. (2013) Trichodina sp'ye japon balığının solungaçlarında, severum (Heros efascatus) ve sarı prensesin ise hem solungaç hem derisinde rastlamıştır. Koyuncu (2006) ise japon balığı (C. auratus)'nın deri ve solungaçlarında rastlamıştır. Kerek ve Özdemir (2016) ise Japon balıklarında \%14 ve Lepisteslerde \%12 oranında tespit etmişlerdir. Çalışmamızda iki adet tetra balığının deri ve solungacında Trichodina sp'ye rastlanmıştır. Bu durum Trichodinaların pek çok tür için patojen olduğunu göstermekle birlikte özellikle derisi ve pulları sert türleri tercih etmediğine de yorumlanabilir.

Gastrotrich türleri hakkında yeterli bilginin mevcut olmamasına karşın tatlı su omurgasızları arasında en bol bulunan türlerdir (Strayer ve ark. 2010). Miah ve ark. (2013) Bangladeş’te yılan kafa (Channa punctatus) balıkları ile yaptığ1 çalışmada Chaetonotus sp'ye balığın solungaçlarında rastlayarak parazitik etki oluşturduğunu bildirmiştir. Bulguroğlu ve Korun (2015) ise yaptıkları çalışmada sadece sarı prenses'te 2 Chaetonotus sp tespit etmiş ve parazite balıkların derisinde rastlamış, solungaçlarda ise rastlamamışlardır. Yapılan çalışmada iki tetra balığının deri ve solungaçlarında Chaetonotus sp'ye rastlanmıştır. Bulunan veriler Miah ve ark. (2013) ile Bulguroğlu ve Korun (2015)'un bulguları ile uyumluluk göstermektedir.

Dactylogyrus sp'nin, discus balıklarında solungaç ve yüzgeçte yerleşen en yaygın parazit türü olduğu bildirilmiştir (Mohammadi ve ark. 2012). Kayış ve ark. (2013)' da yaptıkları çalışmada Symphsodon discusesın solungaçlarında 
Dactylogyrus sp tespit etmişlerdir. Yaptığımız çalışma da en az rastlanan parazitlerden olan Dactylogyrus sp'ye sadece bir vatoz balığının solungacında rastlanmıştır.

Türkiye'de ithalat yoluyla getirilen Japon balıklarında yapılan çalışmalarda en fazla Centrocestus metaserkeri (\%44), Dactylogyrus sp (\%24), daha sonra Ich multifiliis (\%15) ve diger türlerin (Chilodonella sp. (\%10), Argulus sp. (\%5), Trichodina sp. (\%2), Gyrodactylus sp. (\%1)) tespit edildiği bildirilmiştir (Şahin 2004). Parazitlerin hafif enfeksiyonlarında belirgin makroskobik değişiklik olmadığı, sayılarının belli bir seviyenin üzerine çıktıktan sonra makroskobik bulgulara ve ölümlere neden olabileceği (Koyuncu 2002, Kerek ve Özdemir 2016) ve akvaryum balıklarında en öldürücü türlerin ise Ich multifiliis, Trichodina nigra, Chilodonella hexasticha olduğu belirtilmiştir (Koyuncu 2002). Bu çalışmada da her iki türde de en fazla rastlanan parazit Chilodonella sp. olurken, Ich multifilii'e sadece vatoz balıklarında rastlanmışır. Bu durum parazitin gelişim dönemlerini havuz tabanında geçirmesi ve vatoz balıklarının beslenme alışkanlıklarıyla doğrudan ilgili olduğuna yorumlanmıştır.

Melanomakrofaj merkezlerin demir depolama, bakteri ve parazit sporların fagosite etme gibi fonksiyonları yanında endojen zararlı maddeleri detoksifiye etme fonksiyonları da bildirilmiştir. Bu merkezlerin kronik enfeksiyonlarda, çevresel kirlilikde ve stres durumlarında belirgin bir biçimde arttığı belirtilmektedir. Özellikle kronik enfeksiyonlarda melanin içeren pigmentlerde artış olduğu bildirilmiştir (Wolke ve ark 1985; Haaparanta ve ark. 1996; Dönmez 2016). $\mathrm{Bu}$ araştırmada da bir vatoz ve dört tetra balığında dalakta melanomakrofajları içeren pigmentasyon alanları tespit edildi. Bu lezyonların hepsinin parazitle enfeste balıklarda olması, bu balıkların uzun süredir parazitlere maruz kaldığına yorumlanabilir.

Parazitlerin etkileri, parazitin zarar verme şekline, konaklama süresine, konaklama yerine ve konakçılarına göre değişiklik göstermektedir. Deride, bazen yüzgeç dipleri ve solungaçlarda kanamalar, erozyon ve ülserler görülebilir (Roberts 1978, Erer 2009). Solungaçlara yerleşen parazitler ise solunumu engeller. Parazitlerin metabolik artıkları ile bazı salgıları konakçı için toksik, özellikle yavrularda öldürücü etkiye neden olabilirler (Grabda 1991). Bu çalışmada da solungaç, deri, kas ve bağırsaklarda rastlanan lezyonların parazitlerin doğrudan etkileri sonucu oluşan değişiklikler olduğu, dalak ve böbrekteki değişikliklerin ise dolaylı yoldan kronik enfeksiyon ve dolaşım bozukluğu sonucu oluşabileceği kanaatine varıldı. Karaciğerde görülen yağlanmanın ise balıklardaki beslenme bozukluğu sonucu oluştuğu düşünüldü.

\section{SONUÇ}

Patolojik ve parazitolojik incelemeler sonucunda 32 adet Tetra balığında ve 31 adet Vatoz balığında olmak üzere toplamda 63 balıkta parazite rastlandı. İki balık türünden elde edilen veriler birlikte değerlendirildiğinde farklı türde toplam 74 adet ektoparazit olduğu tespit edildi. En çok rastlanan ektoparazit Chilodenella sp (\%51), ardından Costia sp (\%12), Tetrahymana sp (\%11), Ichtyophthirus multifiliis (\%8), Euchlanis sp (\%5), Trichodina sp (\%3), Gastrotricha sp (\%3), Gyrodactylus sp (\%1), Dactylogyrus sp (\%1), Aelosoma sp (\%1), Vorticella sp (\%1) olarak belirlendi. Bu iki balık türü aynı ortamda yaşasalar bile tetra balıklarında vatoz balıklarına göre daha fazla ektoparazit görüldüğü belirlendi, ancak endoparazit görülme oranı vatozlarda daha fazlaydı. Her iki balık türünde de Chilodenella sp'ye oldukça fazla sayıda rastlanması, parazitin tür ayrımı yapmadan aynı ortamdaki farklı türleri enfekte edebileceğini ve işletmelerin özellikle Chilodenella sp’ye karşı koruyucu tedbir alması gerektiğini göstermiştir.

Natif muayenede ektoparazite rastlanmayan balıklarda histopatolojik olarak parazit tespit edilmesi, parazitin olmadığı ya da az olduğu durumlarda natif muayenenin yetersiz kalacağını ve mutlaka histopatolojik incelemenin yapılması gerekliliğini göstermiştir. Histopatolojik olarak yapılan inceleme sonucu kesitlerde rastlanan ekto ve endoparazitlerin tür tayinlerinin yapılabilmesi için immunohistokimyasal boyama veya PCR gibi moleküler tekniklerin kullanılması önerilmiştir. Ayrıca sonraki çalışmaların ithal balıklar üzerinde yapılması ülkeye yeni giren parazitler hakkında fikir verebilir.

\section{ÇIKAR ÇATIŞMASI}

Yazarlar, bu yazı ile ilgili herhangi bir çıkar çatışması olmadığını beyan ederler.

\section{YAZAR KATKISI}

Yazarlar eşit oranda katkı sağlamıştır.

\section{TEŞEKKÜR}

Bu çalışma, yükses lisans tezinden özetlenmiş ve Selçuk Üniversitesi Bilimsel Araştırma Projeleri Koordinatörlüğü tarafindan (Proje No:18202055) desteklenmiştir. 


\section{KAYNAKLAR}

Alpbaz A 1993. Akvaryum. Mas Ambalaj Sanayii ve Tic. A.Ş., Alsancak, İzmir, 403.

Andrews C 1990. The Ornamental Fish Trade and Fish Conservation, J. Fish Biol., 37: 53-59. DOI: 10.1111/j.1095$\underline{8649.1990 . t b 05020 . \mathrm{x}}$

Bulguroğlu SY, Korun J 2015. Bazı akvaryum balıkları ( Chchlidae ve Poecilidae)'nda rastlanılan ektoparaziter enfestasyonların araştırılması. Akdeniz Üniversitesi, Fen Bilimleri Enstitüsü,Su Ürünleri Mühendisliği Anabilim Dalı, Yüksek lisans tezi, Antalya

Cengizler İ 2000. Balık Hastalıkları ders kitabı. Çukurova Üniv. Su Ürünleri Yayınları, yayın no:7, Adana, 136.

Doğanay A, Bozan H, Öge S 1989. Ankara'da bazı akvaryum balıklarında görülen parazitler, A. Ü. Vet. Fak. Derg., 36 (2): 795-806.

Dönmez AE 2016. Balıklarda melanomakrofaj merkezleri. Ege Journal of Fisheries and Aquatic Sciences, 33(1): 8187.DOI: : 10.12714/egejfas.2016.33.1.12

Ekingen G 1983. Tatlısu Balık Parazitleri. Fırat Üniversitesi Su Ürünleri Yüksekokulu. Yay. No:1, Elazı̆g.

Erer H 2009 Balık Hastalıkları Kitabı, 3. Baskı. Konya. Güler Ofset.

Gandini CV, Boratto IA, Fagundes DC, Pompeu PS 2012. Estudo da alimentação dos peixes no rio Grande à jusante da usina hidrelétrica de Itutinga, Minas Gerais, Brasil. Iheringia Ser Zool. 102(1):56-61. DOI: 10.1590/S007347212012000100008

Grabda J 1991. Marine Fish Parasitology: An Outline PWN-Polish Scientific Puplisher, Warszawa, 306pp.

Haaparanta A, Valtonen ET, Hoffmann R, Holmes J 1996. Do macrophage centres in freshwater fishes reflect the differences in water quality? Aquatic Toxicology, 34: 253-272. DOI: $10.1016 / 0166-445 X(95) 00042-3$

Hekimoğlu MA 2004. Akvaryum Balıklarının Önemi ve Sektörün Dünyadaki ve Türkiye'deki Genel Durumu. Akvaryum Dünyas1, cilt:1, sayı:4, p. 18-19.

Hekimoğlu MA 2006. Akvaryum Sektörünün Dünyadaki ve Türkiye'deki Genel Durumu. E.Ü. Su Ürünleri Dergisi, Cilt/Volume 23, Ek/Suppl. (1/2): 237-241

Hoffman GL 1979. Chilodenella hexasticha (Kiernik, 1909) (protozoa, Ciliata) From North American WarmWater fish, Journal of Fish Diseases, 2, 153-157.

https://en.wikipedia.org/wiki/Hypostomus, Erişim 05.04.2019

https://species.wikimedia.org/wiki/Euchlanis. Erişim 05.04.2019

Işık N, Güçlü F, Ceylan O 2016. Parasites detected in Discus fishes (Symphsodon discus) Eurasian J Vet Sci, 32, 3,

Kayış Ş, Balta F, Serezli R, Er A 2013. Parasites on different ornamental fish species in Turkey. J FisheriesSciences.com, 7, 114-120.

Kayış S, Ozcelep T, Capkin E, Altinok I 2009. Protozoan and metazoan parasites of fish in the Turkey and their applied treatments. IJA, 61, 93-102.

Kerek G ve Özdemir Ö 2016. Konya bölgesinde yetiştirilien akvaryum balıklarından Lepistes (Poecilia reticulate)ve Japon balıklarında (Carassius auratus) patolojik ve parazitolojik incelemeler. SÜ Sağ.Bil. Enst. Yüksek lisans tezi, Konya.

Koyuncu CE 2002. Yetiştiriciliği yapılan bazı akvaryum balıkları (Cyprinidae ve Poecilidae)'nda rastlanılan ektoparazitler, histopatolojileri ve sağaltım uygulamaları. Doktora Tezi, Çukurova Üniv., Fen Bilimleri Enstitüsü, Adana, $122 \mathrm{~s}$.

Koyuncu CE 2006. Mersin bölgesinde japon (Carassius auratus L., 1758) balıkları yetiştiriciliği yapan bir akvaryum işletmesinde görülen Trichodina sp. enfestasyonu, Ege Üniversitesi Su Ürünleri Dergisi, 23(3-4): 327-330.

Koyuncu CE 2009. Parasites of ornamental fish in Turkey, Bull. Eur. Ass. Fish Pathol., 29(1), 25

Lievens B, Frans I, Heusdens C, Juste A., Janstrup S.P, Lieffrig F, and Willems KA 2011. Rapid detection and identification of viral and bacterial fish pathogens using a DNA array-based multiplex assay. J Fish Diseases, 34, 861-875. DOI: $\underline{10.1111 / \mathrm{j} .1365-2761.2011 .01304 . \mathrm{x}}$

Luna LG 1968. Manual of histologic staining methods of the armed forces institue of pathology. $3^{\text {rd }}$ ed, Mc Graw-Hill Book Company, New York, p. 32-44.

Magalhaes ALB, Bazzoli N, Santos GB, Rizzo E 2004. Reproduction of the South American dogfish characid, Galeocharax knerii, in two reservoirs from upper Paraná River basin, Brazil. Environ Biol Fishes, 70(4):415-425.

Mankhakhet S, Suanyu N, Tantıkıttı C, Phromkunthangn W, Krıratnıkom S, Lerssutthıchawal T and Vırıyapongsutee B 2012. Diplomonad flagellates of some ornamental fish cultured in Thailand. The Songklanakarin Journal of Science and Technology, 34(5), 484-494.

Miah MF, Deb M, Ali H, Quddus MMA, Ahmed K 2013. Comparative surveillance of parasitic infestation in Channa punctatus (Osteichthys: Channidae) Collected from open and closed water in Sylhet, Bangladesh. Advances in Zoology and Botany, 1(1): 17-23.

Mohammadi F, Mousavi SM, Rezaie A 2012. Histopathological study of parasitic infestation of skin and gill on Oscar (Astronotus ocellatus) and discus (Symphysodon discus). AACL Bioflux, 5, 88-93.

Nelson JS 1994. Fishes of the World, 3rd edition. John Wiley \& Sons, New York: 
Öktener A 2003. A Checklist of Metazoan Parasites Recorded in Freshwater Fish from Turkey. Zootaxa 394, 1-28

Özer A 1999. The Relationship Between Occurrence of Ectoparasites, Temperature and Culture Conditions: A Comparasion of Farmed and Wild Common Carp (Cyprinus carpio L., 1758) in the Sinop Region of Northern Turkey. J. Natural Histology, 33(4): 483-491(9).DOI: 10.1080/002229399300209

Resmi gazete 27.12.2002. 24976 sayılı Ticarette Standardizasyon Tebliği'ne göre "Damızlık Harici Canlı Hayvanlar" kategorisi (Tebliğ No: 2003/5).

Ribeiro Neto FB, Höfling JC, Ferreira LI, Romano CEA 1998. Distribuição, reprodução e alimentação de Galeocharax knerii no reservatório de Salto Grande, macro-regiões de Campinas, SP. Bioikos, 12(2):19-25.

Roberts RJ 1978. Fish Pathology. Baillere Tindall a Division of Case Ltd. Printed in Great Brition at the Univrsty Press. Aberdeen, London, pp 318.

Roberts RJ 2012. Fish Pathology.Wiley \& Sons. London.

Stoskopf K 1993. Fish Medicine. W.B. Saunders Comp. London. 883 p.

Strayer D, Hummon W and Hochberg R 2010. Gastrotricha. In: J Thorp, A Covich, eds. Ecology and Classification of North American Freshwater Invertebrates, 3rd Edition. London, England: Academic Press. pp. 163-172.

Şahin G 2004. İthal edilen altın balıkların (Carassius auratus auratus) ektoparazitolojik olarak incelenmesi. Yüksek lisans tezi, Ankara Üniversitesi Fen Bilimleri Enstitüsü Su Ürünleri Ana Bilim Dalı, Ankara.

Texas Parks and Wildlife 2012. Freshwater Aquarium Hobbyists and Invasive Species in the Houston-Galveston Region. Final Project Report produced by Houston Advanced Research Center (HARC). Texas, USA. http://www.harc.edu/publication/695

Tınar R, Umur Ş 2015. Balıkların Paraziter Hastalıkları. In: Veteriner Parazitoloji, Ed: Tınar R, Umur Ş, Güneş Tıp Kitabevi, Ankara, Türkiye, pp: 233-315.

Türkmen G ve Alpbaz A 2001. Türkiye’ye İthal Edilen Akvaryum Balıkları ve Sonuçları Üzerine Araştırmalar. EÜ Su Ürünleri Dergisi, 18(3-4), 483-493.

Tolon T, Emiroğlu D 2014. Akvaryum baliklari pazar yapisi ve tüketici tercihlerinin değerlendirilmesi, I. Ulusal Akvaryum Balıkçılığı ve Sorunları Çalıştayı Sonuç Raporu, Antalya

Ürkü Ç ve Yardımcı RE 2013. Melek balıklarında (Pterophyllum scalare) Capillaria sp. Enfestasyonu ve Bakteriyel septisemi, J. Fisheries Sciences.com, 7(3): 232 240. DOI: 10.3153/jfscom.2013024

Wolke RE, Murchelano RA, Dickstein CD, George CJ, 1985. Preliminary evaluation of the use of macrophage aggregates (MA) as fish health monitors. Bulletin of Environmental and Contamination and Toxicology, 35: 222227. DOI: $10.1007 / \mathrm{BF} 01636502$.

Yanar M 1998. Akvaryum balıkları yetiştiriciliği ders notu, Çukurova üniversitesi Su ürünleri yayınları, Adana. 